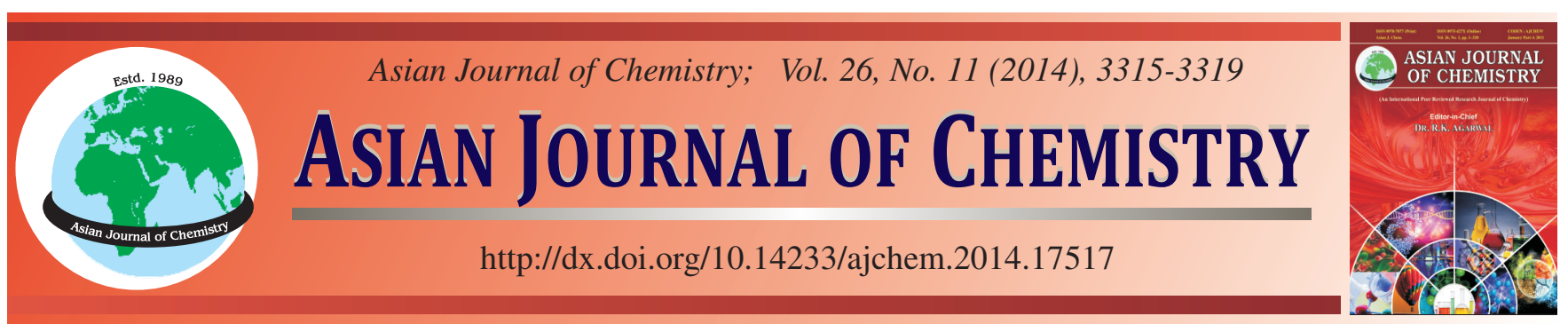

\title{
Enhancing the Production of Human-Like Collagen II by Adding L-Methionine During High-Cell-Density Fermentation of Recombinant Escherichia coli
}

\author{
Lei GUO ${ }^{1,2}$, YAN'E LUO $^{1,2, *}$ and DAIDI FAN ${ }^{1,2}$
}

\begin{abstract}
${ }^{1}$ Shaanxi Key Laboratory of Degradable Biomedical Materials, School of Chemical Engineering, Northwest University, Xi'an 710069, P.R. China ${ }^{2}$ Shaanxi R \& D Center of Biomaterials and Fermentation Engineering, School of Chemical Engineering, Northwest University, Xi'an 710069 , P.R. China
\end{abstract}

*Corresponding author: Fax: +86 29 88302348; Tel: +86 29 88302632; E-mail: luoyane@nwu.edu.cn

\begin{abstract}
Recombinant Escherichia coli BL21 was used to produce human-like collagen II (HLC) in fed-batch cultivation. The effects of feeding strategies of L-methionine on $\mathrm{Y}_{\mathrm{p} / \mathrm{x}}$ (yield coefficient, $\mathrm{HLC} / \mathrm{DCW}, \mathrm{g} \mathrm{g}^{-1}$ ), $\mathrm{OD}_{600}$ and acetate were investigated. In order to gain the highest $\mathrm{Y}_{\mathrm{p} / \mathrm{x}}, \mathrm{L}$-methionine feeding strategy was optimized. The optimum operation was that $1.2 \mathrm{~g} / \mathrm{L}$ of L-methionine should be added at the start of thermal induction. When $1.2 \mathrm{~g} / \mathrm{L}$ of L-methionine was added at the start of thermal induction, $\mathrm{Y}_{\mathrm{p} / \mathrm{x}}$ and cell $\mathrm{OD}_{600}$ could reach $0.2 \mathrm{~g}^{-1}$ and 137 and they were raised by 25 and $9.6 \%$, respectively, while the concentration of by-products acetate was reduced to the safety level for cell growth and HLC synthesis.
\end{abstract}

Keywords: Fed-batch culture, Human-like collagen II, L-Methionine, Recombinant Escherichia coli.

\section{INTRODUCTION}

Human-like collagen II (HLC) expressed by recombinant Escherichia coli BL21 containing a modified cDNA fragment transcribed from special mRNA coding for human collagen was water-soluble novel biomaterial and had a tri-helix structure ${ }^{1}$. The advantages of HLC were low immunogenicity, easily modifiable and no virus risk, hitherto, a few studies have focused on application of HLC in tissue engineering for the construction of artificial bone and vascular scaffold ${ }^{2,3}$.

It was well known that amino acids were the precursor of proteins and very important components for biomass. During amino acid starvation, cells of $E$. coli elicited a swift down regulation of rRNA biosynthesis and ribosome production, known as the stringent response $\mathrm{e}^{4,5}$, but these biosynthesis can be improved upon the coordinated addition of amino acids $s^{6,7}$, meanwhile, the synthesis and stability of recombinant protein could be enhanced due to timely addition of amino acids ${ }^{6}$. Previous studies had showed that methionine could relieve acetic acid inhibition in $E$. coli fermentation ${ }^{8}$ and growth of $E$. coli at an elevated temperature was inhibited when the endogenous supply of methionine was lower than its requirement ${ }^{9}$.

In nature, the natural methionine mainly existed as L-methionine. In order to enhance HLC production during fed-batch cultivation, L-methionine was introduced into culture media. While the addition strategies of amino acids, such as including addition time, addition dose and feeding methods, affected the real results remarkably. In this study, the effects of L-methionine feeding strategies on HLC synthesis, cell growth, by-products and RQ were taken into consideration so as to yield the highest production of desired protein.

\section{EXPERIMENTAL}

Strain and medium: Recombinant $E$. coli BL21, the strain producing HLC, carrying a plasmid pNWCP31 with kanamycin resistance and promoter $\mathrm{P}_{\mathrm{R}} / \mathrm{P}_{\mathrm{L}}$ was constructed and stored in our laboratory ${ }^{10}$. Luria-Bertani medium was used as the seed medium. The batch and feeding media were listed in Table-1. The trace element solution used was reported previously ${ }^{11}$.

Fed-batch culture: Fed-batch cultivation was carried out in an in situ autoclaved fermentor $(12.8 \mathrm{~L}$, Bioengineering Co., Switzerland) with $6 \mathrm{~L}$ of batch media. Cultivation temperature was $34^{\circ} \mathrm{C}$, aeration rate was $18 \mathrm{~L} / \mathrm{min}$ and the fermentation controller kept dissolved oxygen (DO) around a preset level of $30 \%^{12}$. The $\mathrm{pH}$ was automatically maintained at 6.8 by addition of aqueous $\mathrm{NH}_{4} \mathrm{OH}(25 \% \mathrm{w} / \mathrm{w})$. When the glucose in the medium was exhausted, the feeding process started and when $\mathrm{OD}_{600}$ reached around 95 , the cultivation temperature 


\begin{tabular}{ccc}
\hline \multicolumn{3}{c}{ TABLE-1 } \\
MEDIUM COMPOSITIONS \\
\hline Components & $\begin{array}{c}\text { Medium for batch } \\
\text { culture }(\mathrm{g} / \mathrm{L})\end{array}$ & $\begin{array}{c}\text { Medium for fed culture } \\
(\mathrm{g} / \mathrm{L})\end{array}$ \\
\hline Glucose & 30.0 & 1000.0 \\
Yeast extract & 50.0 & 400.0 \\
$\mathrm{~K}_{2} \mathrm{HPO}_{4}$ & 5.6 & 26.0 \\
$\mathrm{NaH}_{2} \mathrm{PO}_{4}$ & 3.4 & 12.6 \\
$\left(\mathrm{NH}_{4}\right)_{2} \mathrm{SO}_{4}$ & 4.2 & 16.5 \\
$\mathrm{MgSO}_{4}$ & 1.8 & 20.0 \\
EDTA & 0.8 & 3.0 \\
Trace element & 0.6 & 3.0 \\
Antifoam & 0.1 & - \\
\hline
\end{tabular}

was shift to $42^{\circ} \mathrm{C}$ for $3 \mathrm{~h}$ for induction and then the temperature was lowered to $39^{\circ} \mathrm{C}$ for $3 \mathrm{~h}$ to achieve a high production level of HLC.

Fermentation controller based on an on-line operating system: The fermentation controller (Silicon Labs) recorded some key fermentation parameters such as $\mathrm{pH}$, stirring speed, temperature, DO and feeding rate. In this fermentation controller, on-line monitoring by direct-drive actuators was achieved through the control commands issued by the D/A conversion. And the stirring speed and feeding rate were then controlled by preset control algorithms based on an independent variable, $\mathrm{DO}^{12}$.

Analysis methods: Cell density was measured at $600 \mathrm{~nm}$ with a spectrophotometer (UNICO Model 2082PCS, USA). The cell concentration was determined by the DCW (dry cell weight); the broth sample was centrifuged, washed three times with distilled water and dried to a constant weight in an oven with a set temperature of $105^{\circ} \mathrm{C}$. Organic acids in the broth were analyzed by high-performance liquid chromatography (HPLC) using Shimadzu Shim-pack $\mathrm{C}_{18}$ reverse phase column, VP-ODS ( $250 \mathrm{~mm} \times 4.6 \mathrm{~mm}, 5 \mu \mathrm{m})$ and Shimadzu Shim-pack G guard column $\left(\mathrm{C}_{18}, 10 \mathrm{~mm} \times 4 \mathrm{~mm}, 5 \mu \mathrm{m}\right)$. Human like collagenII was determined by hydroproline colorimetry ${ }^{13}$. The $\mathrm{CO}_{2}$ and $\mathrm{O}_{2}$ concentrations in the inlet and outlet gas were measured on-line by a gas analyzer (LKM2000A; Lokas Automation) and the oxygen uptake rate (OUR) and carbon dioxide evolution rate (CER) were calculated on-line, accordingly ${ }^{14}$. The residual amino acids in the broth were analyzed by high-performance liquid chromatography (HPLC) using a Dikma AAA amino acids analysis column, VP-ODS (250 $\mathrm{mm} \times 4.6 \mathrm{~mm}, 5 \mu \mathrm{m})$.

Analysis of amino acid distribution: Amino acids were of great importance in the synthesis of HLC and biomass and there was some disagreement between the production of HLC and biomass because HLC was a kind of exogenous protein to E. coli. In order to increase the productivity of HLC, it was necessary to analyze the metabolic flux distribution of amino acids. Based on the conservation of total mass, the metabolic flux of amino acid (i) was shown in Fig. 1.

Fig. 1 showed that the metabolism of most amino acids consisted four parts: (1) from cells to medium (or reverse); (2) the synthesis of biomass; (3) the synthesis of HLC; (4) fluxing into intermediate metabolites or forming amino acids.

\section{RESULTS AND DISCUSSION}

Screening the dosage of L-methionine by shake-flask culture: E. coli BL21 grew at $34{ }^{\circ} \mathrm{C}$ in a $250 \mathrm{~mL}$ of flask containing $50 \mathrm{~mL}$ Luria-Bertani medium in a shaker at 220

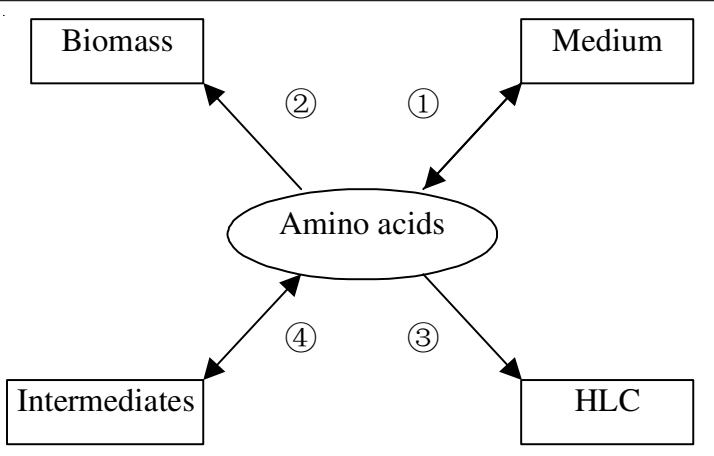

Fig. 1. Schematic pathways of amino acids

rpm. When $\mathrm{OD}_{600}$ was around 4.5-5.0, the temperature was increased to $42^{\circ} \mathrm{C}$ for $3 \mathrm{~h}$ and then lowered to $39^{\circ} \mathrm{C}$ for $3 \mathrm{~h}$ to achieve a high production level of HLC. All experiments were performed in triplicate.

As shown in Fig. 2, L-methionine could affect cell growth and HLC synthesis significantly, which implied that L-methionine in LB medium might not meet the need of cell growth and HLC synthesis and the extra addition of L-methionine with a suitable dosage could benefit to biomass and HLC systhesis no matter of the addition time. Methionine, a sulfurcontaining amino acid, was essential for the whole biological kingdom because of their prominent tasks in metabolism ${ }^{15}$. The appropriate dosage of methionine could increase cell growth in our study, which had been approved in previous studies $^{8}$. Meanwhile, $\mathrm{Y}_{\mathrm{p} / \mathrm{x}}$ presented a peak when $0.6 \mathrm{~g} / \mathrm{L}$ of L-methionine was added both at start of cultivation and induction (Fig. 2C). It was well known that methionine was required not only for initiating protein synthesis, synthesizing restored proteins and incorporating into proteins, but also for various methylation reactions, hence control of its amount in cell would monitor cell growth and the synthesis of key intermediate S-adenosylmethionine (SAM) directly ${ }^{8,9}$. During high temperature induction, the elevated temperature usually blocked the formation of methionine by decreasing the activity of the first enzyme of the methionine pathway and then affected cell growth and protein synthesis ${ }^{9}$, so adding methionine timely could increase biomass and protein production (Fig. 2). In addition, the appropriate addition of L-methionine increased $Y_{p / x}$, which further confirmed that methionine from yeast extract could not meet the need of cell growth and exogenous protein synthesis (data not shown). And optimum addition dosage of L-methionine was $0.6 \mathrm{~g} / \mathrm{L}$ in shake-flask culture.

Scale-up fermentation: The results of single-factor experiment with shaking flask showed that addition of methionine could make a positive contribution to the cell growth and $Y_{p / x}$ and then scale-up fermentation was carried out by fed-batch culture.

Four growth phases could be identified during fed-batch cultivation of recombinant E. coli BL21 as following: Phase I, in which $E$. coli BL21 adapted to the fermentation environment and grew at the maximum specific growth rate in batch medium; phase II, in which glucose feeding started when phase I ended with glucose exhaustion; phase III, in which the cultivation temperature was shift to $42{ }^{\circ} \mathrm{C}$ to induce HLC expression for $3 \mathrm{~h}$ when $\mathrm{OD}_{600}$ reached around 100 and phase $\mathrm{IV}$, in which the cultivation temperature was decreased to $39^{\circ} \mathrm{C}$ and main- 

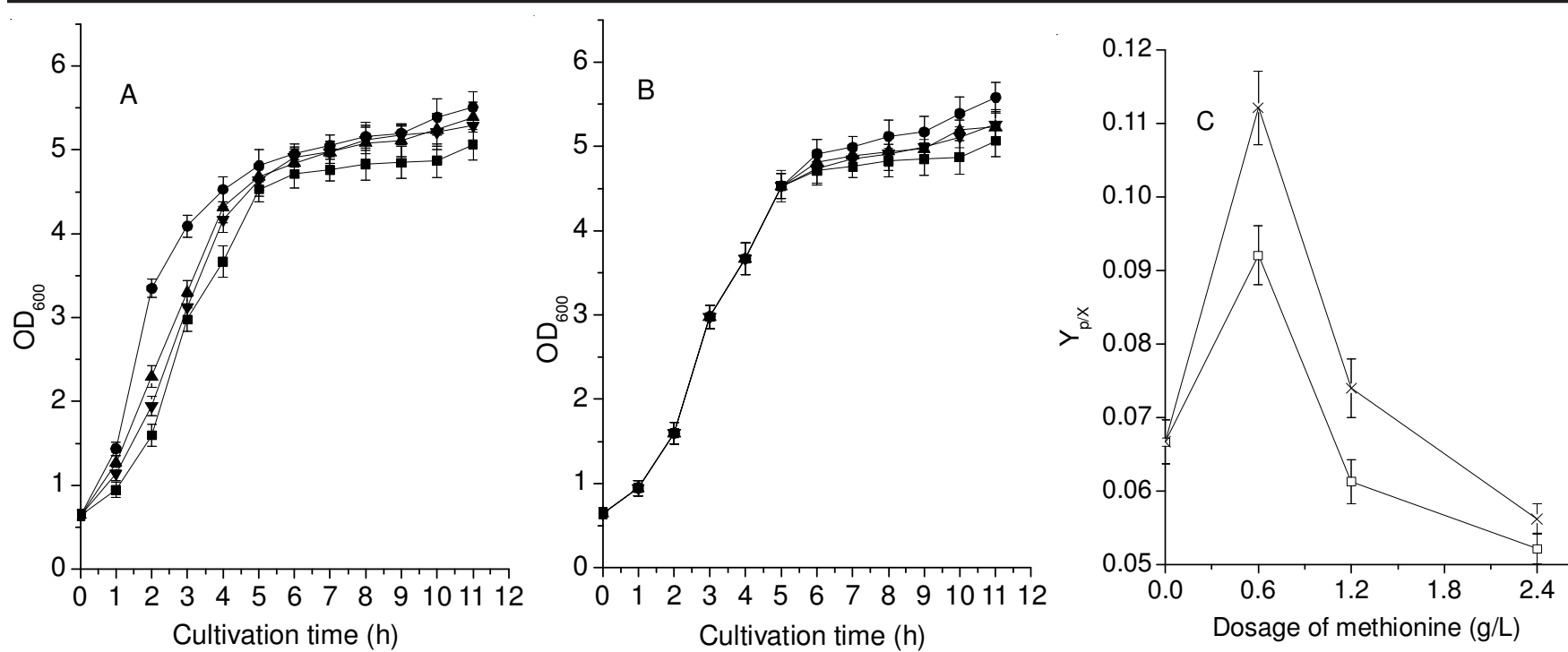

Fig. 2. Time profiles of OD600 and Yp/x of batch culture performed at different addition time and dosage of L-methionine were presented. Fig. 2A described that methionine was added at the start of cultivation with different dosage; Fig. 2B described that L-methionine was added at the start of induction with different dosage, and Fig. $2 \mathrm{C}$ presented the difference in $\mathrm{Yp} / \mathrm{x}$ under the different addition time and dosage of L-methionine. " $\square$ " was the control; "O" presented $0.6 \mathrm{~g} / \mathrm{L}$ of L-methionine was added; " $\mathbf{\Delta}$ " presented $1.2 \mathrm{~g} / \mathrm{L}$ of $\mathrm{L}$-methionine was added; " $\nabla$ "meant $2.4 \mathrm{~g} / \mathrm{L}$ of L-methionine was added; " $\square$ " presented that L-methionine was added at the start of cultivation; and " $\times$ " presented that L-methionine was added at the start of high temperature induction

tained for $3 \mathrm{~h}$ to achieve a high HLC production. Since the transfer properties of mass and energy were different in shakeflask culture and bioreactor culture, the addition protocol of methionine was changed on the base of shake-flask cultivation and listed as following (Table-2).

\begin{tabular}{|c|c|}
\hline & $\begin{array}{c}\text { TABLE-2 } \\
\text { ADDITION PROTOCOL OF METHIONINE }\end{array}$ \\
\hline Run & Details of addition protocol of methionine \\
\hline $\mathrm{C}$ & Control with no addition of methionine \\
\hline I & $\begin{array}{l}0.6 \mathrm{~g} / \mathrm{L} \text { of methionine was added at the start of culture by one } \\
\text { time }\end{array}$ \\
\hline II & $\begin{array}{l}1.2 \mathrm{~g} / \mathrm{L} \text { of methionine was added at the start of culture by one } \\
\text { time }\end{array}$ \\
\hline III & $\begin{array}{l}2.4 \mathrm{~g} / \mathrm{L} \text { of methionine was added at the start of culture by one } \\
\text { time }\end{array}$ \\
\hline IV & $\begin{array}{l}0.6 \mathrm{~g} / \mathrm{L} \text { of methionine was added at the start of induction by } \\
\text { one time }\end{array}$ \\
\hline V & $\begin{array}{l}1.2 \mathrm{~g} / \mathrm{L} \text { of methionine was added at the start of induction by } \\
\text { one time }\end{array}$ \\
\hline VI & $\begin{array}{l}2.4 \mathrm{~g} / \mathrm{L} \text { of methionine was added at the start of induction by } \\
\text { one time }\end{array}$ \\
\hline VII & $0.6 \mathrm{~g} / \mathrm{L}$ of methionine was flown in after induction \\
\hline VIII & $1.2 \mathrm{~g} / \mathrm{L}$ of methionine was flown in after induction \\
\hline IX & $2.4 \mathrm{~g} / \mathrm{L}$ of methionine was flown in after induction \\
\hline
\end{tabular}

Effects of methionine on cell growth and $Y_{p / x}$ : Being same to the above results of shake-flask culture, extra addition of methionine could make a positive contribution to cell growth and HLC synthesis during fed-batch cultivation (Fig. 3). During fed-batch cultivation, $1.2 \mathrm{~g} / \mathrm{L}$ of methionine was more beneficial to cell growth and HLC synthesis than the other dosages despite of the different addition time and methods. And the yields of HLC $\left(\mathrm{Y}_{\mathrm{P} / \mathrm{X}}\right)$ were similar between methionine addition performed by one time addition at the start of culture and by flowing in during the induction phase (Fig. 3D). When methionine was added by one time at the start of high temperature induction seemed to lead to the highest yield of HLC
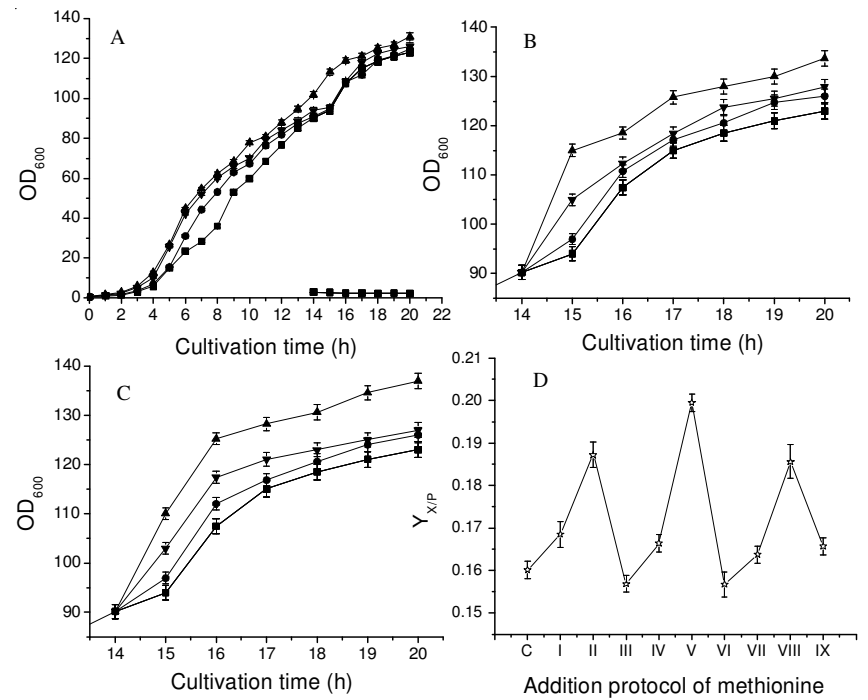

Fig. 3. Process curves of fed-batch cultivation performed with nutrientDO feedback control at the different addition strategies of methionine were presented. Fig. 3A, Fig. 3B and Fig. 3C described that methionine was added by one time at the start of cultivation with different dosage, added by one time at the start of thermal induction with different dosage, and flown in during the induction with different dosage, respectively. And Fig. 3D described that YP/ $\mathrm{X}$ of HLC at different addition protocol listed in Table-2. "口" was the control; "O" presented $0.6 \mathrm{~g} / \mathrm{L}$ of methionine was added; " $\mathbf{\Delta}$ " presented $1.2 \mathrm{~g} / \mathrm{L}$ of methionine was added; " $\boldsymbol{\nabla}$ " presented $2.4 \mathrm{~g} / \mathrm{L}$ of methionine was added

$\left(\mathrm{Y}_{\mathrm{P} / \mathrm{X}}\right)$ (Fig. 3D). During high temperature induction, the temperatures of $42-44^{\circ} \mathrm{C}$ could limit cell growth rate by decreasing the activity of the first enzyme of the methionine synthetic pathway in E. coli, homoserine trans-succinylase ${ }^{9,16}$. Although high temperature leaded to no irreversible damage to the cell by inhibiting the synthesis either of protein or of RNA due to the rapid cease of both these syntheses ${ }^{9}$, methionine could restore protein synthesis to activate cell growth ${ }^{9}$. So the addition 
of methionine by one time at the start of high temperature induction was more effective than the others. Perhaps the concentration of methionine in broth added by flowing in was lower than the real need of cells, then addition of methionine by flowing in did show any superiority.

According to metabolic network of E. coli growing in the medium with glucose served as the sole carbon source ${ }^{18,25}$, twenty kinds of amino acids that ultimately combine to form the protein product, ten of them are biochemically derived from TCA cycle precursors, eleven of them are derived from glycolysis precursors and four of them are derived from the pentose phosphate pathway. Moreover, pyruvate and the intermediate metabolites ( $\alpha$-ketoglutarate and oxaloacetate) of TCA cycle serve as the precursors for the thirteen kinds of amino acids synthesis, on the base of the compositions of total proteins needed for producing $1 \mathrm{~g}$ biomass, $73.9 \%$ precursors for synthesizing amino acids were from pyruvate and TCA cycle $^{17}$. Actually, when the synthesis of recombinant protein started, the onset of "protein burden" could lead to a decrease in glycolytic flux and growth rate ${ }^{18}$. A large number of pyruvate and the intermediate metabolites in TCA cycle were needed to form the amino acids of protein, which resulted in an imbalance flux if the precursors of pyruvate and TCA cycle intermediate metabolites diminished continuously. Consequently, it might result in a limitation in cell growth and recombinant protein synthesis. It was clearly that, replenishing the key amino acids, especially the amino acids whose biosynthetic pathways were inhibited by cultivation conditions, should provide a feasible way to improve recombinant protein production.

Reducing hazardous by-products: Glucose could be converted into some specific by-products when the growth rate of the microorganisms exceeded a suitable range, the broth lacked oxygen, or the dose of glucose did not match that of nitrogen ${ }^{19}$. Moreover, these specific by-products were hazardous to microorganisms, especially acetic acid which was harmful to cell growth and collagen synthesis if its amount exceeded $2 \mathrm{~g} / \mathrm{L}^{20}$. Therefore, it was important to decrease the amount of by-products.

Previous studies showed that the effects of methionine on acetate-mediated inhibition of growth could be replicated for other organic acids ${ }^{8}$. Mutants with an elevated intracellular methionine pool were almost completely resistant to the yield inhibitory effects of acetate, suggesting that the methionine pool become limiting for growth in acetate-treated cells ${ }^{16}$.

Acetic acid, as a major by-product of $E$. coli metabolism, was found to be hazardous to cell growth and protein synthesis. Acetic acid could interfere with methionine biosynthesis and finally brought in a greater inhibitory to recombinant proteinproducing cells $\mathrm{s}^{21}$. After the thermal induction, oxygen transfer rate (OTR) reached the maximum value, the excessive glucose could not be oxidized completely and a portion of the available glucose was converted to acetic acid for ATP and NADH formation $^{22}$. As shown in Fig. 4, methionine played a very important role to affect the formation of acetic acid. After the thermal induction of recombinant $E$. coli BL21, it was very important to choose a reasonable strategy of methionine addition. The level of acetic acid reduced to the safety range when $1.2 \mathrm{~g} / \mathrm{L}$ of methionine was added by one time after the thermal induction. The mechanism of methionine in relieving the acetic acid inhibition was unclear. Some researchers thought it might be related to glycine the conversion from serine to glycine which was regulated by methionine, methionine addition could increase serine hydroxymethyltransferase level to produce more glycine and the extra increase of glycine might increase the concentration of active cytochrome enzyme complex leading to an increased respiration capacity ${ }^{8}$. As shown in Fig. 5, cell activity and respiration capacity of the strains with the addition of extra methionine were higher than that without the addition of extra methionine. So cell growth could be restored by adding methionine even under high level of acetic acid. And acetic
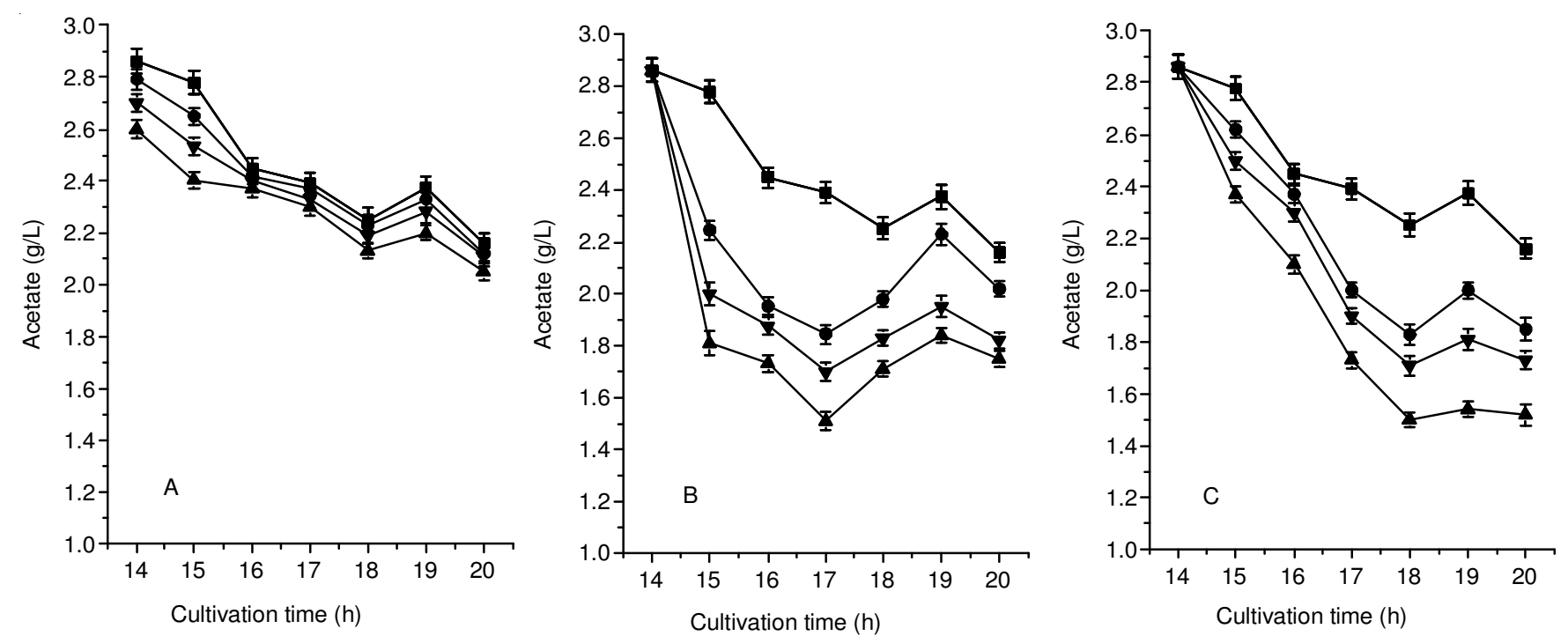

Fig. 4. Time profiles of acetic acid during fed-batch cultivation with nutrient-DO feedback control at the different strategies of methionine addition were presented. Fig. 4A, Fig. 4B and Fig. 4C described that methionine was added by one time at the start of cultivation with different dosage, added by one time at the start of induction with different dosage, and flown in during the induction with different

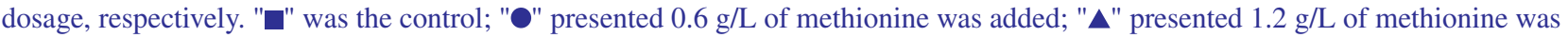
added; " $\boldsymbol{\nabla}$ " presented $2.4 \mathrm{~g} / \mathrm{L}$ of methionine was added 

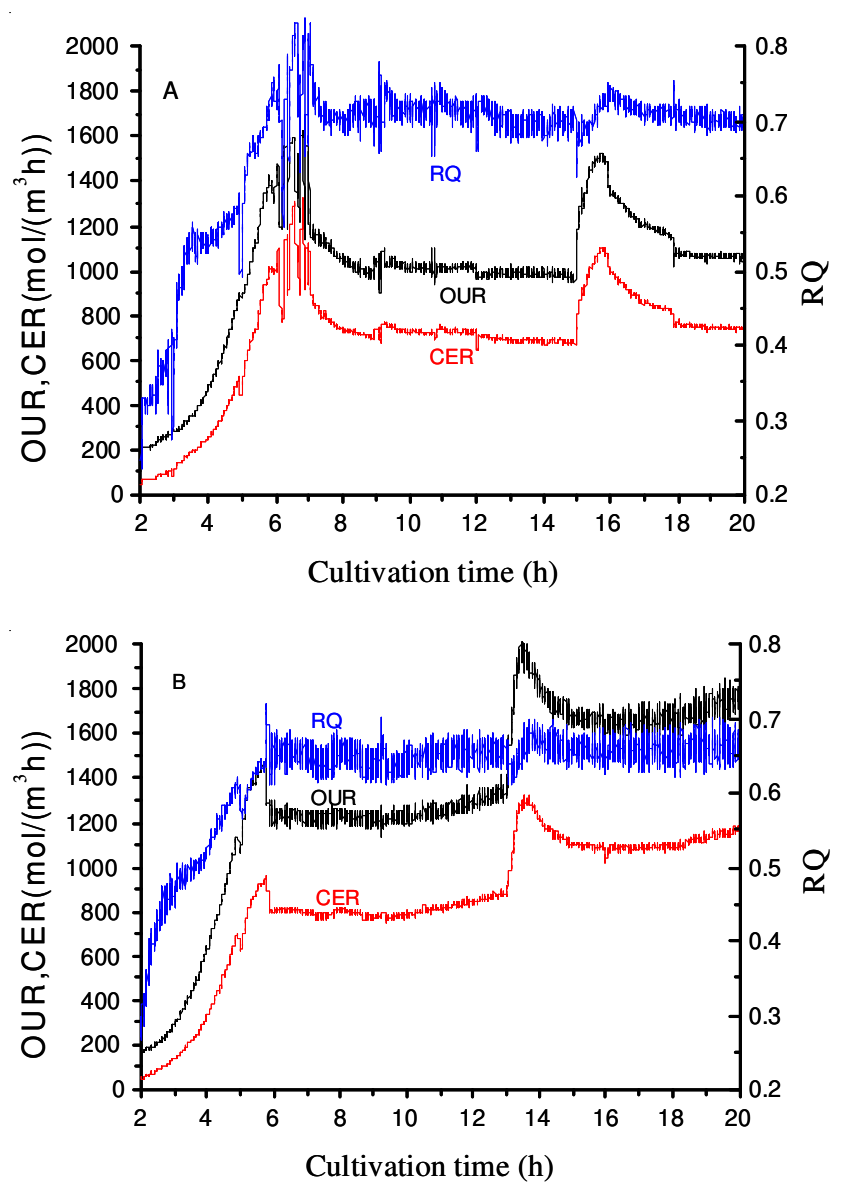

Fig. 5. Curves of OUR, CER and RQ with/without adding $1.2 \mathrm{~g} / \mathrm{L}$ of methionine. Fig. 5A was the control without adding methionine; Fig. 5B was the treatment with adding $1.2 \mathrm{~g} / \mathrm{L}$ of methionine

acid was used as carbon source if glucose concentration was below the critic point of carbon catabolite repression (CCR). Finally, acetic acid level reduced significantly.

Further, the change of acetic acid confirmed the optimum dosage and addition method of methionine was $1.2 \mathrm{~g} / \mathrm{L}$ and one-time addition at the start of thermal induction. This result was agreed to the addition strategy to bring in the highest HLC yield. As for heterogenous protein expression, the maintenance and expression of heterologous protein production required both the precursors of a specific protein and energy demand ${ }^{23}$. In order to compensate the increase in energy demand, cell metabolism fluxes were reorganized for ATP regeneration ${ }^{24}$. Additional ATP formation could be obtained by increasing the flux from pyruvate to acetyl-CoA and later towards acetic acid $^{19}$. Methionine was a precursor of protein, the addition of some key precursors could reduce the energy demand for the protein synthesis ${ }^{25}$. The balance between energy demand and precursor demand was directly reflected to the metabolic fluxes and cell physiology ${ }^{26}$. Methionine addition benefited to this balance and produced more desired protein but less acetic acid.

\section{Conclusion}

During shake-flask culture and fed-batch culture of recombinant $E$. coli to produce heterogeneous protein, methionine addition could enhance cell growth and HLC yield. Especially, the growth of $E$. coli at $42{ }^{\circ} \mathrm{C}$ could be strengthened by the extra supplement of endogenous methionine. What's more, the growth inhibition under organic acids could be eliminated with endogenous methionine addition to some extent.

\section{ACKNOWLEDGEMENTS}

This study was financially supported by National Natural Science Foundation of China [21176200]; the Scientific Research Program of Shaanxi Provincial Department of Education, China [2010JC21, 2010JS107, 2010JS108 and 2010JS109].

\section{REFERENCES}

1. Y.E. Luo, D.D. Fan, X.X. Ma, D.W. Wang, Y. Mi, X.F. Hua and W.H. Li, Chin. J. Chem. Eng., 13, 276 (2005).

2. C.H. Zhu, D.D. Fan, Z.G. Duan, W.J. Xue, L.A. Shang, F.L. Chen and Y.E. Luo, J. Biomed. Mater. Res., 89A, 829 (2009).

3. C.H. Zhu, D.D. Fan, X.X. Ma, W.J. Xue, Y.Y. Yu, Y.E. Luo, B.W. Liu and L. Chen, J. Bioact. Compat. Polym., 24, 560 (2009).

4. G.S. Stent and S. Brenner, Proc. Natl. Acad. Sci. USA, 47, 2005 (1961).

5. M.K. Sands and R.B. Roberts, J. Bacteriol., 63, 505 (1952).

6. D.M. Ramirez and W.E. Bentley, Biotechnol. Bioeng., 41, 557 (1993).

7. K.C. Thomas and W.M. Ingledew, Can. J. Microbiol., 38, 626 (1992).

8. K. Han, J. Hong and H.C. Lim, Biotechnol. Bioeng., 41, 316 (1993).

9. E.Z. Ron and B.D. Davis, J. Bacteriol., 107, 391 (1971).

10. D.D. Fan, M.R. Duan, Y. Mi, J.R. Song, J.F. Xi, D.W. Wang and G.Z. Wang, J. Ind. Eng. Chem., 53, 752 (2002) (in Chinese).

11. D.J. Korz, U. Rinas, K. Hellmuth, E.A. Sanders and W.-D. Deckwer, J. Biotechnol., 39, 59 (1995).

12. T.Z. Mu, Y. Luo, D.D. Fan, L. Guo and J. Cao, Adv. Mater. Res., 535537, 2312 (2012).

13. M.W. Yin, Y.M. Nan and X.M. Wang, J. Henan Med. Univ., 29, 74 (1994) (in Chinese).

14. S. Jin, K. Ye and K.J. Shimizu, J. Ferment. Bioeng., 80, 541 (1995).

15. K. Saito, Plant Physiol., 136, 2443 (2004).

16. A.J. Roe, C. O'Byrne, C.D. McLaggan and I.R. Booth, Microbiology, 148, 2215 (2002).

17. J.L. Snoep, L.P. Yomano, H.V. Westerhoff and L.O. Ingram, Microbiology, 141, 2329 (1995).

18. Y.E. Luo, D.D. Fan, L.A. Shang, H.J. Shi, X.X. Ma, Y. Mi and G.F. Zhao, Biotechnol. Lett., 30, 637 (2008).

19. K. Han, H.C. Lim and J. Hong, Biotechnol. Bioeng., 39, 663 (1992).

20. G.W. Luli and W.R. Strohl, Appl. Environ. Microbiol., 56, 1004 (1990).

21. B.T. Koh, U. Nakashimada, M. Pfeiffer and M.G.S. Yap, Biotechnol. Lett., 14, 1115 (1992).

22. M.A. Eiteman and E. Altman, Trends Biotechnol., 24, 530 (2006).

23. J. Heyland, M.L. Blank and A. Schmid, J. Biotechnol., 155, 178 (2011).

24. F. Hoffmann and U. Rinas, Biotechnol. Bioeng., 76, 333 (2001).

25. J. Weber, F. Hoffmann and U. Rinas, Biotechnol. Bioeng., 80, 320 (2002).

26. F. Hoffmann and U. Rinas, Adv. Biochem. Eng. Biotechnol., 89, 73 (2004). 